many different points of view, and those who wish to make propaganda on the subject should be careful to make it clear what their grounds are. Since decisions affecting science involve extra-scientific considerations, scientific research should continue to be based in the universities and not in government establishments, for in the universities it is easier for the scientific worker to maintain contact with specialists in other disciplines.

In discussion, Dr. E. V. Rowsell spoke of the scientific workers' responsibility to make public the potential consequences of their discoveries. They have no right to put such scientific discoveries as nuclear fission into the hands of governments without explaining to the layman what is involved. He contended that, if the public had fully realized the implications of the use of the atomic bomb, they would not have permitted it to be used, even to end the war with Japan. Prof. D. H. Peacock urged men of science to tolerate religion even if they do not themselves subscribe to it: religion might be as good an ethical basis for science as any of the alternatives that have been put forward.

Summing up the last session, Prof. Mott agreed that the special responsibility of the man of science lies in disseminating the consequences of scientific progress, while Prof. Coulson urged a search for a basis of agreement, for example, between religion and Marxism. True science, he said, is itself a religious activity, and religion and science are facets of something greater than either.

A. F. Brown

A. R. TRIM

\section{ASTRONOMY AT THE CAPE OF GOOD HOPE}

\section{ANNUAL REPORT FOR 1950}

T HE Report for 1950 of H.M. Astronomer at the Cape of Good Hope, Dr. R. H. Hoy, to the Secretary of the Admiralty has recently been published*. The report commences with a description of the buildings and grounds; certain modernizations of the residences have been undertaken and work on an improved water supply to the offices and residences has been started. Minor repairs were made to the dome of the Tower telescope and an improved gear fitted; leaks in the dome of the Victoria telescope can be repaired, but it is necessary to re cover the astrographic dome with 'Masonite', owing to its age and general condition. An account of the alterations to and use of the nine instrumente follows, and in some cases there have been delays in adapting them to the scheduled programmes. Thus, while the modernization of the reversible transit circle went on throughout 1950 , it was impossible to bring it back into routine use during the year, though it had been hoped that it would be in a fit state to start the new observing programme during the first half of 1951. The photometric cameras were received back from the Cambridge Observatory early in 1950; but they will probably remain unmounted until after the reversible transit circle is in active commission. The old gravity-driven clock for the Victoria telescope has been replaced by a small electric synchronous motor ;

* Report of H.M. Astronomer at the Cape of Good Hope to the Secretary of the Admiralty for the Year 1950. Pp. 15. (Cape of Good Hope: Royal Observatory, 1951.) the new compound cell for the 24-in. lens has been received from Messrs. Cox, Hargreaves and Thompson, Ltd. ; but it has not yet been fitted. The Airy transit circle, which was used chiefly for making differential observations, has been dismantled as the observations can be made more accurately and more conveniently by the reversible transit circle.

Under "Astronomical Observations and Reduc. tions" are included meridian observations, photo. graphic star positions and proper motions, and stellar photometry, with seven subdivisions. An interesting matter arises under "Occultations" in connexion with the occultations of Antares in May and June. This star is one of the few occulted that can be expected to show a measurable diameter, and preparations were made at the Radcliffe and Cape Observatories to observe the May and June occultations photoelectrically with the object of measuring the durations of the occultations and from these deducing the apparent diameter of the star. Successful observations indicated a diameter of $0.04^{\prime \prime}$, and it was realized that it would be a simple matter to time ordinary occultations to an accuracy of 0.01 sec. with a slight modification of this photoelectric apparatus. Arrangements have already been made for this, and it is hoped that occultations will be timed photoelectrically in the routine work. It may be pointed out that a photomultiplier photoelectric photometer has been in use for some time with the 15 -in. reflector at Dunsink Observatory, and an occultation can be timed with an accuracy of one-hundredth of a second by this method (see Irish Astro. J., 1, No. 6 ; 1951).

Other matters referred to in the Report are the time service, meteorological observations, publication of results and personal establishment. The lastnamed concludes with an account of the work of Dr. J. Jackson, who succeeded Sir Harold Spencer Jones at the Cape in March 1933, and who retired at the end of July 1950. This account pays tribute to Dr. Jackson's devotion to the parallax work in particular; during the Second World War, when many of the staff were absent on war duties, he personally made a large proportion of the necessary observations ; and after the War, when the Observatory was fully staffed, he continued to observe up to the time of his retirement, especially on the photometry of the parallax stars. On relinquishing his appointment he was made a C.B.E.

\section{THE QUAIL IN BRITAIN}

THE widespread impression that, in the British Isles, the quail used to be more a resident and less of a summer naigrant is probably fallacious. There are still records of quail here every winter, and there is no evidence that the proportion of winter birds to summer birds is less than it ever was in the past. This and other problems of the biology of the quail have recently been discussed by R. E. Moreau (British Birds, 44, No. 8, 257, August 1951).

Unlike the other game-birds, the quail is not represented by archrological or fossil material in the British Isles and there is no mention of it before the twelfth century. Evidently the bird never established itself here in the affections of the common people, as it did in Germany, where it was a cherished songster and unrestrained household pet. Nor in Great Britain or Ireland did the bird insinuate itself into proverbial sayings as it did in Germany, France and Italy. It 
may be inferred, therefore, that it was less common in the British Isles, though there are enough contem. porary references to show that some centuries ago quails were much more numerous and widespread here than they are now.

Towards the end of the twelfth century, for example, Giraldus Cambrensis reported "coturnices hic plurimi" in Ireland. In fifteenth-century literature the term "bevy of quails" occurs repeatedly. In 1466 quails (a hundred dozen) figured in the banquet given for Archbishop Nevill of York at Cawood, and in 1422 quails were included in the coronation feast of Henry VI.

In the sixteenth and seventeenth centuries significant references to quails are numercus : none of the English game-laws (eight up to 1714) mentions quail. But the birds were evidently an esteemed article of diet, and it may be inferred that up to 1700 the quail was a familiar bird in both Great Britain and Ireland and was usually regarded as rather a speciality for the table and probably diminishing, but still plentiful enough to be worth the bird-catcher's attention.

There are remarkably few direct references to the quail in the eighteenth century; but it is doubtful whether it diminished much. At the beginning Morton noted that "it comes into the sandy and warmer soil" of western Northants "at least a fortnight before it settles in the colder clayey part of the county".

There was undoubtedly a marked and progressive decline of quail in Britain in the first half of the nineteenth century; but this was accompanied by a marked increase in Ireland about 1845-50, when several nests could be found in one field. The subsequent decline, perhaps delayed until about 1865, was so marked that by the 1880 's quail had almost totally disappeared from Ireland.

In 1865 More assessed the status of quail in Britain on the basis of questionnaires and concluded that "there are few counties in which the quail is considered to breed annually". In the remaining counties of Great Britain the quail was classed as "occasional". It seems that by about 1865 the quail in England had reached nearly the low ebb to which it fell in the twentieth century except for an occasional 'good' year.

To-day, systematic bird reports are produced annually for nearly thirty Lnglish counties. Quail records in these reports can be supplemented from the occasional county avifauna and from other records. These figures show that 1936 was the worst year in the twentieth century, the next worst being 1935 and 1940. Except for 1946. every year from 1944 onwards shows a more widespread recording of quail than any year before 1944 .

In the present century there have been in the British Isles no quail years so outstanding as 1870 and 1893; but, allowing for various factors, it is probably true that at least twice as many quail visited Britain in 1947 as in any other year this century. 1947 was also a peak year in Belgium, Switzerland, Sweden and Holland.

Most of the records of quail in Britain are from areas of chalk, greensand and oolite. Of the eight most favoured counties six are dominated by these formations, and in them, as in Yorkshire, a very high proportion of the localities named in the quail records are calcareous. It is doubtful how far this correlation is due to preference for these soils and how far to preference for associated land-use.

Throughout its range the quail is a bird of open country, frequenting annual herbaceous growth, so that the deforestation of Europe must greatly have increased the area the bird can inhabit. There has been conflict of opinion about the effect of the sub. sequent agriculture. For example, in Norfolk the bird was said to like "rough fens", and its nineteenthcentury decline has been attributed to the break-up of "coarse tussocky land". Others take the view that the decline of the quail was associated with "the great reduction in acreage of arable". Certainly the increase in quail since 1942 has accompanied a great. increase in arable; but it must be recalled that in the first half of the nineteenth century, when arable was expanding in both Great Britain and Ireland, the quail was declining in the former as markedly as it was increasing in the latter.

While some have thought that clover fields are the favourite habitat of the quail, most observers believe that corn-fields are most frequented. Corn has been given as the quail's first preference in Germany, in Savoy and in Holland.

In Britain the prevalence of quail in corn as com. pared with other crops is likely to be accentuated by modern developments. On one hand the practices of grass-drying and silage-making lead to earlier cutting of some of the forage crops: on the other hand, increase in autumn-sowing of corn results in a bigger proportion of the area under corn being able to offer adequate cover to quail as soon as they arrive.

It is doubtful whether the decline of the quail population in the British Isles, which had to some extent a parallel in Western Europe as a whole, was due to changes in agricultural methods and in particular to the introduction of the mowing machine; human predation has probably been the most import. ant factor in the decline of the quail population. Up to a few years ago exploitation on both sides of the Mediterranean was merciless in both spring and autumn, and the birds were not even left alone during the breeding season. From Egypt alone, as late as $1913,1,858,000$ quail were exported; with a general fall in the quail population the Egyptian exports in the years 1930-34 varied between 285,000 and 580,000, more than half the birds being captured as they were travelling north to breed. In 1937, import of live quail earlier than July was prohibited in both the main consuming countries, France and Britain, and the spring taking of quail was prohibited in both Egypt and French North Africa. The traffic in quail stopped in 1939 on the outbreak of war and has not. been resumed.

Protection of quail visiting Britain has been inadequate and illogical. A hundred years ago, the stock had already been so reduced that no more should have been shot. Yet the quail still can be shot during. the close season by owners and occupiers of land on their own land in nearly half the counties of England, including Berkshire, Cambridgeshire, Gloucestershire and Wiltshire, four of the seven counties in which quail are most likely to occur. The proposed new bird-protection legislation should stop these anomalies.

Moreau also discusses certain problems of quail biology and shows that information on the lifehistory of the quail is full of gaps and of conflicting information. In particular, investigation is needed into the relations of the sexes; it seems probable that mated males call little and that polygamy cannot be the rule. Though considerable attention has been given to the subject of the migration of the quail, it is far from being understood. 